\title{
Maturity and Decline in Press Markets of Small Countries. The Case of Austria
}

\author{
Daniel Grabner ${ }^{1}$ and Andrea Grisold ${ }^{2}$
}

\begin{abstract}
Digitalisation, changes in consumer behaviour and the repercussions of the Great Recession seriously threaten the traditional business models of print media. The paper at hand contributes a small state perspective on these issues by analysing the daily newspaper market in Austria in its maturity and decline. We provide a comprehensive overview of the developments and current state of the newspaper industry for the period 2000-2016, with a special emphasis on the move to digital. Thus we examine trends in circulation, online reach and revenue structures. In addition, ownership structures are explored, followed by an analysis of media concentration. We address how media policy, including subsidy schemes, have contributed to the status quo of the Austrian media landscape and evaluate how proposed policy changes take digital transition into account. Finally, core company strategies employed by newspaper enterprises are identified.
\end{abstract}

The second half of the $20^{\text {th }}$ century saw print media companies experience stable growing readerships. Moreover, they were much sought-after as advertising carrying bodies. Both factors led to a comfortable financial situation on the revenue side. Apart from

1 Daniel Grabner is research assistant at the Institute for Institutional and Heterodox Economics, Vienna University of Economics and Business.

2 Andrea Grisold is professor of economics at the Vienna University of Economics and Business, and head of the Institute for Institutional and Heterodox Economics.

Recherches en communication, $\mathrm{n}^{\circ} 44$ - Article publié le 10/04/2018 
their economic success, print media were seen as indispensable in providing a diversity of opinion for the democratic process. Internationally, to varying degrees, press subsidies helped to stabilize the industry. This golden era has since faded. Print media faces considerable losses, concentration tendencies are pervasive, and new challenges emerge in the digital field.

In that regard, Austria's newspaper landscape is no exception. However, some characteristics of the Austrian media market - a small market size with a giant same-language neighbour, a small number of newspaper titles, strong regional players, media concentration both at a national and even more so at a regional level, a strong lean towards boulevard press and a high degree of ownership concentration - amplify or mitigate these developments.

In their seminal work, Hallin and Mancini (2004) conclude that the Austrian media system follows the Democratic Corporatist model, which is characterized by a high-reach press market, strong journalistic professionalism and a perception of media as social institutions that cannot be left to the functioning of the market mechanism alone. However, their comparative approach neglects the size of media systems (Puppis 2009). In the case of Austria, several structural features of media systems in small nations apply: a shortage of resources, limited market sizes, dependence and vulnerability (Trappel 1991, p. 26-34; Grisold 1996).

Historically, after WWII, the allies in concordance with the then newly formed parties established a new press structure. That stated, the new system rested on older, formerly entrenched structures. Such a path dependency characterizes the Austrian press system as well: Not only were traditional papers reestablished, but also journalists, who had collaborated with the Nazis, were not always banned from the profession. 1946, only a year after the end of WWII, saw 36 dailies in the Austrian press market. Not differing from other European countries, a multitude of party press characterized Austria's press market. They declined in the 1970s and 80s, resulting in a decline in titles published.

In the 1980s, the Austrian press market proved to be an attractive option for foreign - and especially German - capital. 
One German publisher acquired a nearly $50 \%$ interest in the two largest dailies; another enabled the market entry of a new quality daily. In the mid-2000s, the advent of free dailies marked another significant change for the Austrian press, once again in accord with international developments.

In this paper, we will analyse the Austrian newspaper market in its maturity and decline. Here maturity refers to the state of the industry as saturated, in the discussion of the press crisis the respective market is seen as declining. In the following sections, we exemplify the Austrian situation along 9 findings: The first four findings sketch development and status quo of the Austrian newspaper industry with a special emphasis on the move to digital, the following three findings deal with Austrian media policy, followed by another two on companies' strategies.

\section{Development and Status Quo}

\subsection{Press concentration formally declined but still prevalent on all levels}

With 15 daily newspaper titles, Austria does not exactly represent the pinnacle of media diversity. The number shrinks further, when only independent newspaper firms are considered. Table 1 provides an overview of the underlying ownership structures of Austrian newspapers. Among Austrian newspapers, family businesses are the most common type of ownership. Other major shareholders include banking groups, a foreign media conglomerate and the Catholic Church. Against the tide, one minor regional daily even remains in ownership of a political party. 


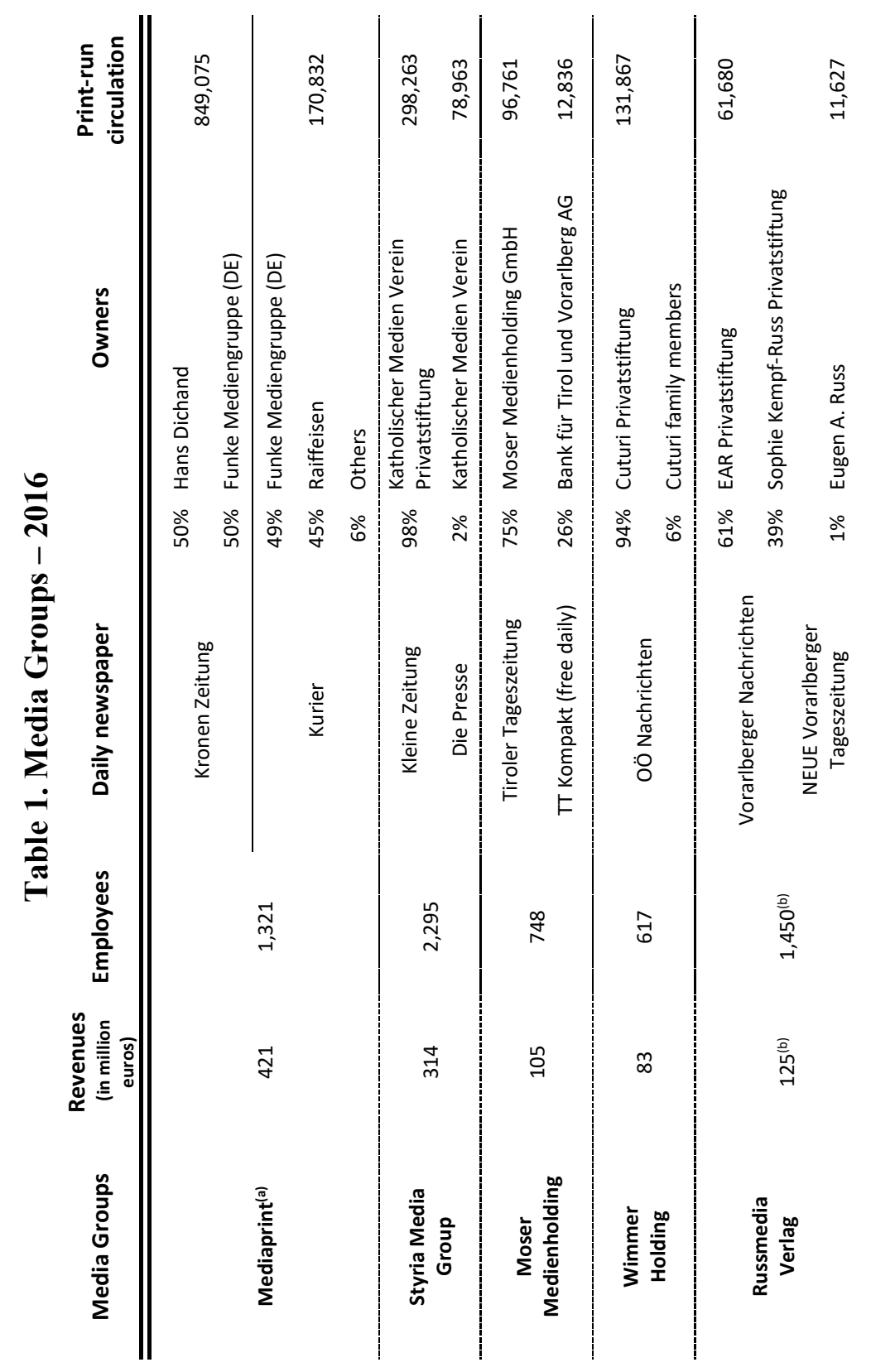




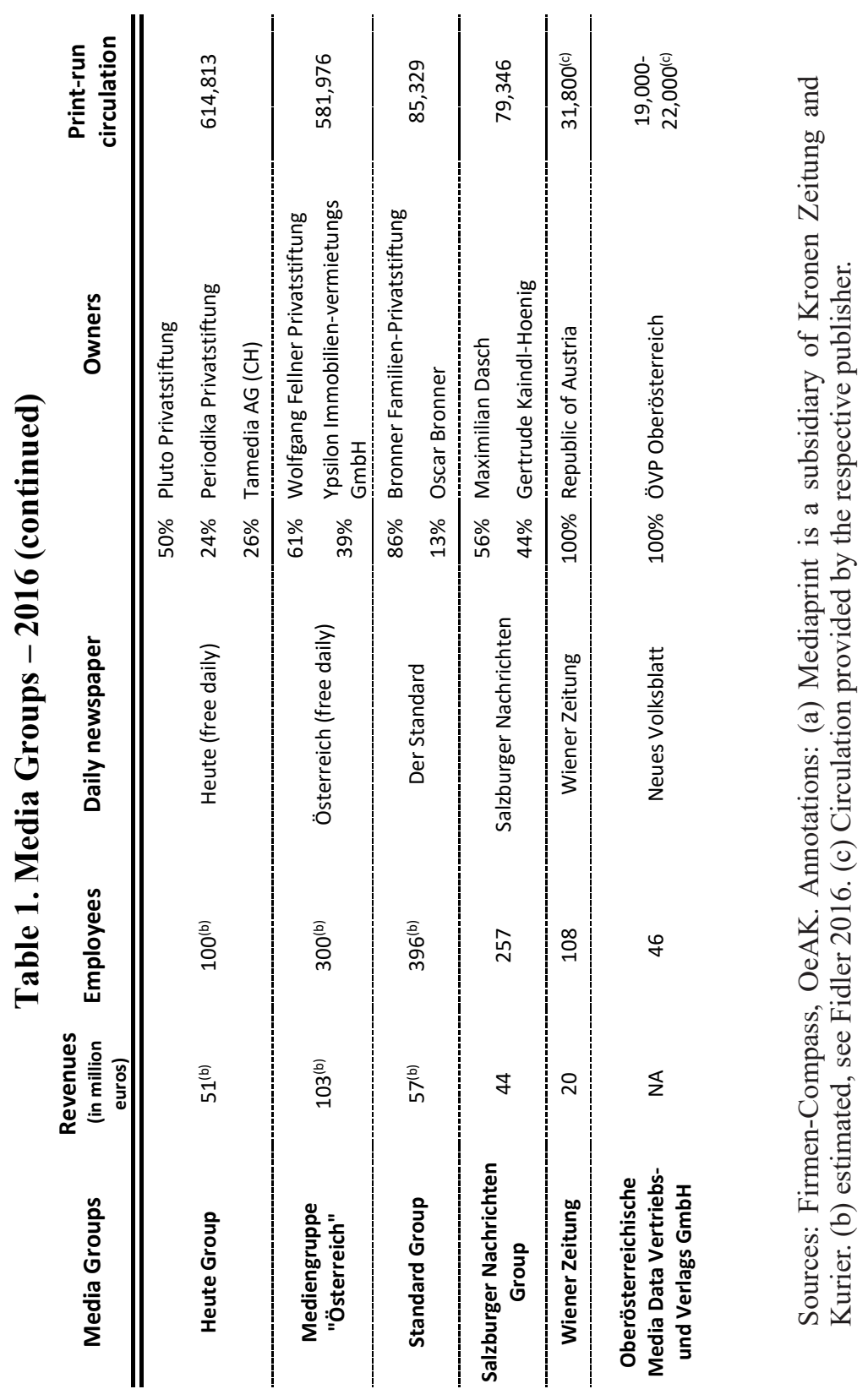


Still the dominant force in Austria's newspaper landscape is Mediaprint, accounting for roughly $50 \%$ of paid-for daily circulation ( $32 \%$ of total daily circulation) in 2016. Formed in 1988 as a subsidiary of the widest-circulating daily, the tabloid Kronen Zeitung and the mid-market paper Kurier, this cooperation of the Dichand family, a foreign media conglomerate and a domestic banking group has an especially strong foothold in Eastern Austria, including Vienna. Austria's newspaper market used to enjoy an almost unprecedented level of concentration. Especially the hegemonic role of Kronen Zeitung acted as a poster child of press concentration in international comparison.

However, the concentration in the newspaper market (see Table 2), quantified by the Herfindahl-Hirschman index (HHI), significantly decreased in the early 2000s and stagnated afterwards (2,042 in 2016 compared to 3,702 in 2000). HHI values between 1,500 and 2,500 are generally considered as moderately concentrated. The Noam index declined as well, the share of the top three groups (C3) less so, and the share of the top four groups (C4) remained stable. The sharp decline in HHI can be attributed to the advent of free dailies, Heute and Österreich, which thrive on a combined circulation of 1.2 million copies or roughly $40 \%$ of the total circulation.

Table 2. Concentration indices based on circulation shares

\begin{tabular}{lccccccccc} 
& $\mathbf{2 0 0 0}$ & $\mathbf{2 0 0 2}$ & $\mathbf{2 0 0 4}$ & $\mathbf{2 0 0 6}$ & $\mathbf{2 0 0 8}$ & $\mathbf{2 0 1 0}$ & $\mathbf{2 0 1 2}$ & $\mathbf{2 0 1 4}$ & $\mathbf{2 0 1 6}$ \\
\hline \hline HHI & 3,702 & 3,638 & 2,779 & 2,194 & 2,208 & 2,144 & 2,108 & 2,075 & 2,042 \\
$\begin{array}{l}\text { Noam-Index } \\
\begin{array}{l}\text { Number of } \\
\text { independent }\end{array}\end{array}$ & 1399 & 1375 & 983 & 731 & 736 & 715 & 703 & 692 & 681 \\
dailies & 7 & 7 & 8 & 9 & 9 & 9 & 9 & 9 & 9 \\
C4 & 0.85 & 0.86 & 0.84 & 0.81 & 0.84 & 0.82 & 0.83 & 0.84 & 0.84 \\
C3 & 0.8 & 0.81 & 0.78 & 0.68 & 0.7 & 0.69 & 0.69 & 0.71 & 0.71
\end{tabular}

Sources: Extrapolation from Firmen-Compass and OeAK 
These findings, however, come with several caveats. First, quantifying concentration as above does not take into account the strong similarities in form and content, e.g. between the free dailies and Kronen Zeitung given their tabloid nature. Second, these indices are computed on a national level, neglecting the distinct regional characteristics of Austria's newspaper market. Regarding the latter argument, the HHI can be computed at a regional level. The nine Austrian federal states represent central regional markets, both for audiences and for the advertising industry (Bakker \& Seethaler 2009, 73). Table 3 shows daily newspapers which are among the top 3 in terms of reach in at least one state. Redefining the relevant markets in this narrower regional level translates into alarmingly high regional $\mathrm{HHI}$ values and reveals quasi-monopolistic structures in several of the states. Furthermore, Table 3 displays the high reach levels the Kronen Zeitung has in most of the federal states. 


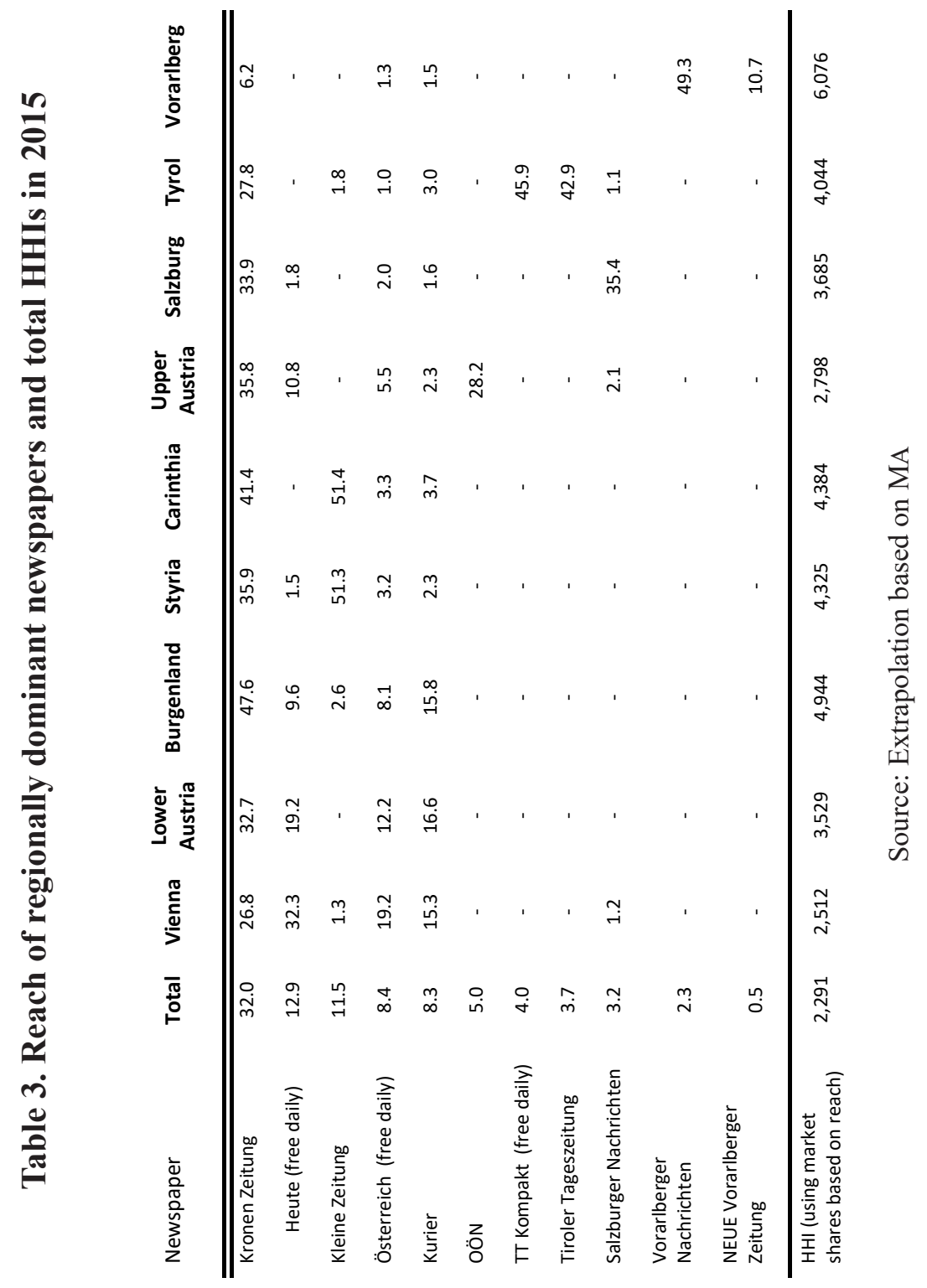




\subsection{Land of the Free (Dailies)}

As mentioned beforehand, the mid-2000s saw the formation of two free dailies (Heute and Österreich), leading to further tabloidization on the Austrian newspaper market. While this development led to a decline in daily newspaper concentration on a statistical level (due to Heute and Österreich being independent media entities), this picture changes at a second glance. Behind both papers lie well-known actors within the industry: While Heute is controlled by Eva Dichand, daughter-in-law of Mediaprint's late Hans Dichand, Österreich is controlled by Wolfgang Fellner, who formerly owned Austria's dominant news magazine group.

\section{Figure 1. Daily Newspapers 2000-2016}

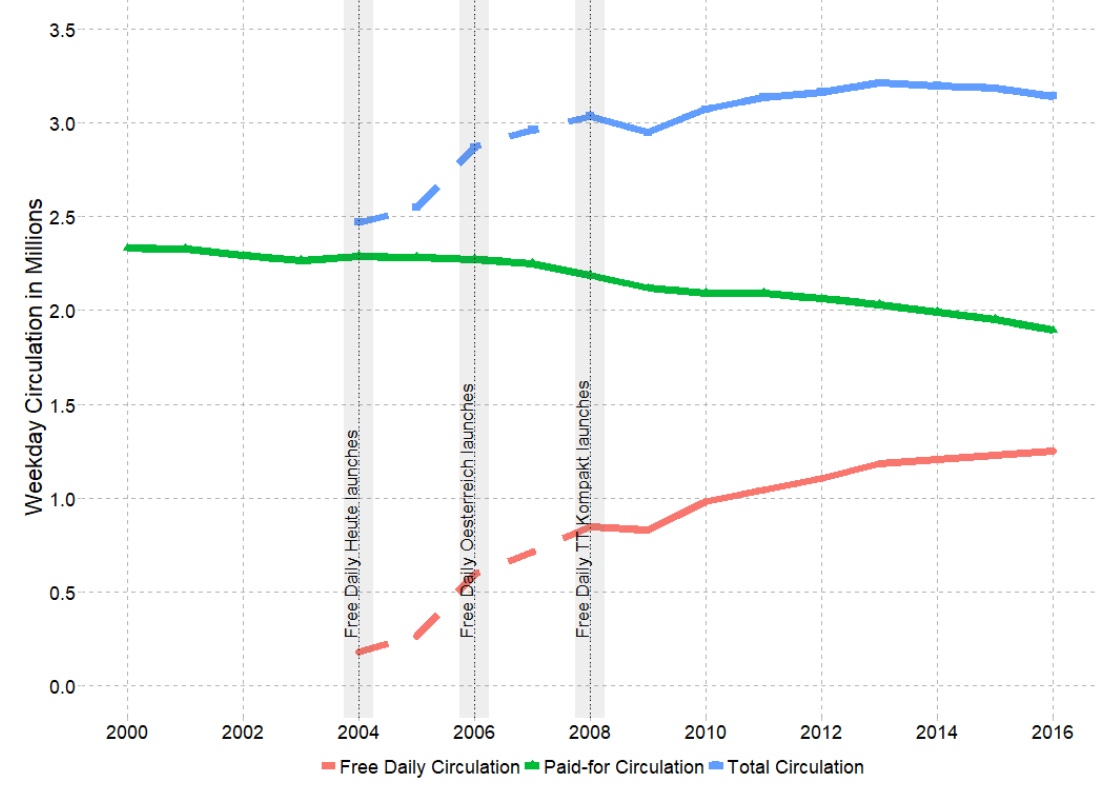

Source: MA; dotted lines are estimates

Figure 1 illustrates the development of the combined weekday print-run of Austria's main daily newspapers. Paid-for newspapers exhibited relative stability until 2008, but are now in decline: With less than 1.9 million copies printed in 2016, 
Austrian print-run numbers for paid-for dailies have fallen to a level last seen in the 1970s (Steinmaurer 2002, 15).

The decline of paid-for dailies is contrasted by the emergence of free dailies, massively offsetting the decline in numbers of total copies. As already mentioned, free dailies account for roughly $40 \%$ of the overall print-run in 2016 . However, the circulation of free dailies temporarily dropped in 2009 and their general growth rates slowed down afterwards.

\subsection{Revenue Structure: Volatile Advertising and Unsustainable Subscriptions}

In terms of advertising market shares, daily newspapers are still the most important vehicle for advertisement in Austria, as seen in Table 4. However, since the data is gathered using list prices, it is rather unreliable, especially considering advertising's sensitivity to business cycles.

To offer a second perspective, we computed net advertising expenditures using tax data. These net figures experienced a decline in 2009 followed by stagnation. It is noteworthy that the ratio of gross to net ad expenditure is steadily increasing since 2008 , indicating that the official list prices were increasingly undercut. Advertising expenditure computed through list prices inflated actual expenditures by a factor of mere 1.17 in 2001 and by 1.84 in 2015 .

As is claimed by Kaltenbrunner $(2013,56)$, the cyclical decline in advertising during the Great Recession was generously counteracted by an expansion of public-sector advertisement. While the data backing this claim is limited, the assertion itself is plausible. In the following years, public debate on state-financed advertisement led to the introduction of media transparency law in 2012. As a consequence, public sector institutions are obligated to report their advertising expenditures. In 2013, the first year of the reporting, public sector advertising totalled 200 million euros, but has been declining since then. In 2015, public spending accounted for $8.5 \%$ (2014: 9.5\%) of gross advertisement in dailies. Assuming that the values for gross advertisement are similarly inflated for 
all media types, one could very well conclude that $15 \%$ of all advertisement in newspapers is financed by the public sector.

Table 4. Gross and net advertising expenditure 2001-2015

$\begin{array}{lllllll}2001 & 2004 & 2007 & 2008 & 2009 & 2012 & 2015\end{array}$

\begin{tabular}{lccccccc}
\hline \hline $\begin{array}{l}\text { Total ad spending } \\
\text { (gross, in million euros) }\end{array}$ & 2,047 & 2,656 & 3,174 & 3,329 & 3,328 & 3,920 & 4,192 \\
\hline $\begin{array}{l}\text { Dailies } \\
\text { (Shares) }\end{array}$ & 27.9 & 21.3 & 22.8 & 23.5 & 23.9 & 25.5 & 25 \\
$\begin{array}{l}\text { TV } \\
\text { (Shares) }\end{array}$ & 22.7 & 18.7 & 18.7 & 18.7 & 18.9 & 19.9 & 24 \\
$\begin{array}{l}\text { Regional weeklies } \\
\text { (Shares) }\end{array}$ & 6.9 & 7.2 & 7.9 & 7.1 & 6.8 & 8 & 8 \\
$\begin{array}{l}\text { Online } \\
\text { (Shares) }\end{array}$ & NA & 0.8 & 2.1 & 2.6 & 3.5 & 4.1 & 6 \\
\hline $\begin{array}{l}\text { Tax revenue (net, } \\
\text { in million euros) }\end{array}$ & 88 & 95 & 108 & 114 & 105 & 110 & 107 \\
$\begin{array}{l}\text { Tax base (net, } \\
\text { in million euros) }\end{array}$ & 1,755 & 1,894 & 2,170 & 2,280 & 2,110 & 2,199 & 2,145 \\
$\begin{array}{l}\text { Total ad spending } \\
\text { minus Online (gross, in } \\
\text { million euros) }\end{array}$ & 2,047 & 2,633 & 3,109 & 3,242 & 3,213 & 3,760 & 3,950 \\
\hline $\begin{array}{l}\text { Ratio of gross to actual } \\
\text { ad expenditure }\end{array}$ & 1.17 & 1.39 & 1.43 & 1.42 & 1.52 & 1.71 & 1.84 \\
\hline
\end{tabular}

Source: Focus-Institut, Statistik Austria.

The other source of revenue for paid-for dailies, subscriptions, remained stable with a decrease of just $1.7 \%$ for the period of 2005 to 2015. Due to increases in prices, we estimated that subscription revenue even increased by $27 \%$ in the respective period. Combining subscription and total revenue data, we obtain 
rough estimates that suggest a clear trend: In 2014, 26\% to $34 \%$ of revenues of paid-for dailies are due to subscription sales. In 2006, the share ranged from $19 \%$ to $25 \%$. Hence, the relative importance of subscription revenue increased significantly within this period. However, it is questionable if these or further price rises are sustainable - especially given the current readership age structure: About $82 \%$ of people over 60 years read newspapers, but usage drops steadily the younger people are, with a minimum

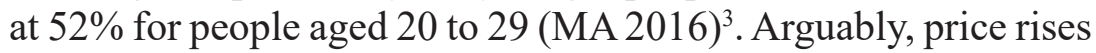
may reinforce this trend.

\subsection{Online outlets: high reach, uncertain business models}

As shown in Figure 2, almost all daily newspapers seem ${ }^{4}$ to reach more readers online than through their print editions. The only exception being Kronen Zeitung, whose sheer dominance on the print market is not overtaken by its online edition. Interestingly, ranking by online reach seems to favour quality newspapers with relatively low distinct regional orientation, such as Der Standard and Die Presse. In 2016, their online reach was four to five times higher than their reach offline. The high online reach of Der Standard may in part be explained by first-mover advantage since it was the first German speaking daily to establish an online outlet.

On a similar note, Thurman (2014) observed that online extensions of UK quality newspapers are comparatively more successful than their tabloid counterparts. He offers two hypotheses. One states that these quality newspapers are simply better at delivering content to a web audience. His other hypothesis is by far more Veblenian in nature (Veblen 1899) and points to the increased consumption of news in the workplace, where usage behaviour is open to judgement from co-workers and managers.

3 Recent studies indicate that this trend can be mainly attributed to a distinct cohort effect, i.e. the currently young audiences are not very likely to shift towards increasing print media consumption as they grow older (Best/ Engel 2016).

4 Online and offline reach is collected by different institutions using different methods. Data on online reach is not available for all news outlets. 
Hence, quality newspapers are preferred since they indicate a higher socio-economic status.

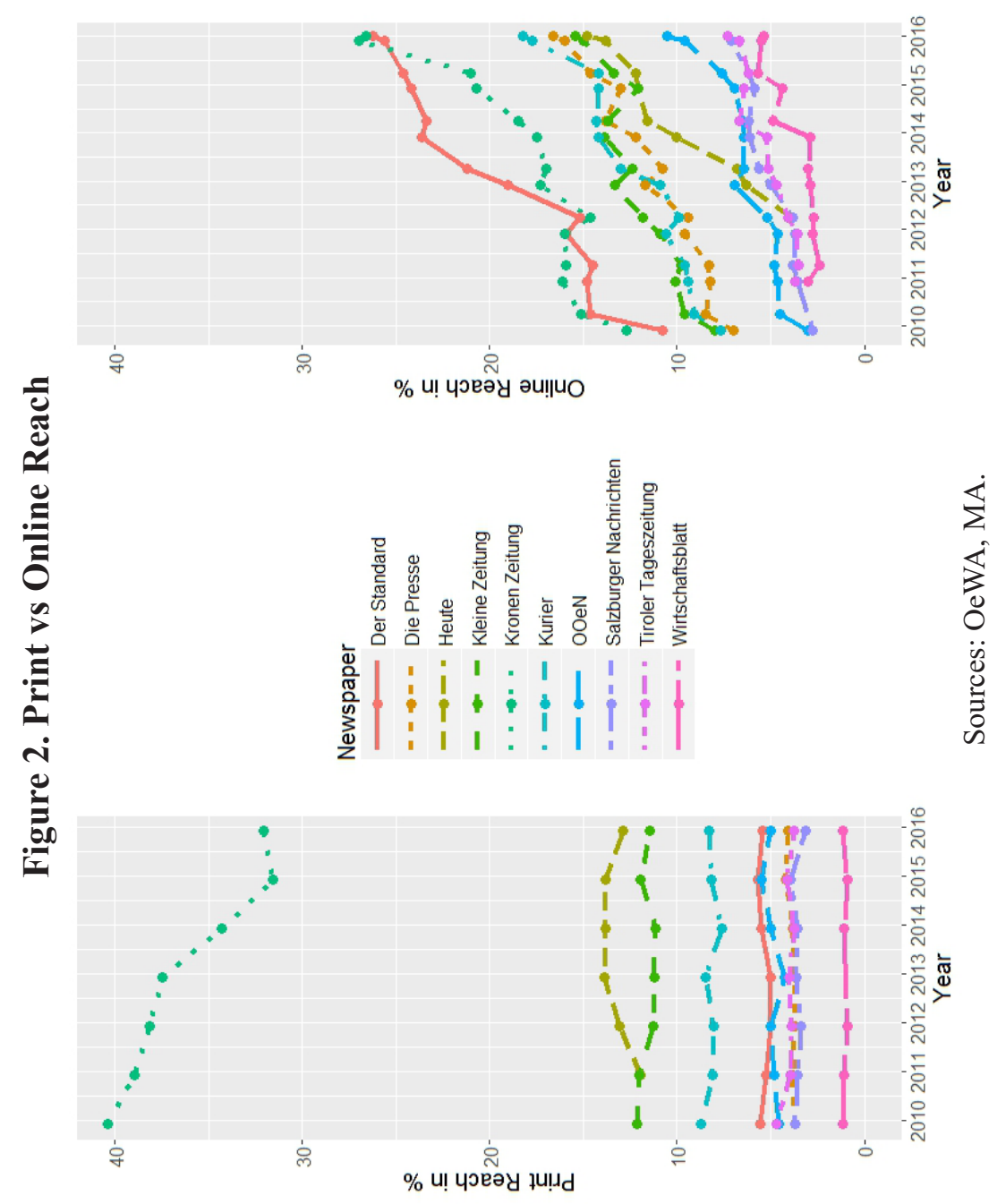


Newspaper platforms are among the most popular websites used in Austria, for example, derStandard.at ranks $10^{\text {th }}$ according alexa.com (2016). It seems that people using the internet for news consumption resort to brands and companies already established in traditional media. Indeed, offline preferences often determine online news consumption, especially for those who read tabloid or regional newspapers, as Trilling and Schoenbach (2013) show for Austria. The observations regarding offline-online news consumption also coincide with empirical findings from other countries, e.g. Germany (van Eimeren \& Koch 2016).

The bulk of digital content is distributed without charges. Subscriptions of newspapers in e-paper format have increased, but amount to only $3.1 \%$ of total subscriptions in 2016 (2.4\% in 2015). One remarkable outlier, the business newspaper Wirtschaftsblatt, had $15 \%$ of its subscribers use its e-paper edition. However, the circumstance that the newspaper had to close down by the end of 2016 casts a shadow of doubt on its possible role as a digital pioneer for the industry.

\section{Media Policies in Austria}

The main reason to introduce or maintain state activity in favour of the newspaper sector is to keep as many newspapers as possible in the market, ideally to encourage new releases as well (surmisable for online papers only these days). This is seen as securing diversity of opinion, a necessary condition for democracy. The question to be asked in that context is: Should the preservation of the newspaper structure be regarded as desirable? How to deal with the ongoing switch to digital consumption/ outlets?

\subsection{Direct Press Subsidies are Helpful for Small Countries}

Most European countries have a number of indirect press subsidies, i.e. measures that involve a cost reduction for the newspaper firms (tax cuts, low postal rates, etc.), as does Austria. Quite unique for Austria and a few Scandinavian countries are 
direct press subsidies (according to certain fixed criteria, grants are given directly to the newspaper firms, without a specified usage).

2015 saw the $40^{\text {th }}$ anniversary of the press subsidy law in Austria. Currently, subsidies are provided for the distribution of newspapers (subsidies go to all daily papers on their request - smaller amount), for contributions to regional diversity (to a few papers considered especially important for the diversity of opinions - larger amount) and for the professional development of journalists (smallest amount). ${ }^{5}$ As shown in Table 5, the amount allocated to the press declined in two steps since the Great Recession.

Table 5. Press subsidies in $€$ mil

\begin{tabular}{cccccc} 
Year & Total & Distribution & Diversity & Quality & Self-regulation \\
\hline \hline 2016 & 8.45 & 3.80 & 2.97 & 1.52 & 0.16 \\
2015 & 8.88 & 3.87 & 3.24 & 1.56 & 0.20 \\
2014 & 8.65 & 3.71 & 3.24 & 1.53 & 0.16 \\
2013 & 10.84 & 3.89 & 5.24 & 1.56 & 0.15 \\
2012 & 10.79 & 3.92 & 5.29 & 1.58 & - \\
2011 & 12.38 & 4.36 & 6.41 & 1.61 & - \\
2010 & 12.84 & 4.52 & 6.65 & 1.67 & - \\
2008 & 12.84 & 4.52 & 6.65 & 1.67 & - \\
2006 & 12.84 & 4.53 & 6.64 & 1.67 & - \\
2004 & 13.48 & 4.76 & 6.99 & 1.73 & -
\end{tabular}

Source: RTR

The distribution subsidies are non-targeted subsidies. Historically, the introduction of an - albeit reduced - VAT taxation for newspapers in 1974 led to complaints by Austrian newspaper editors, followed by a press subsidy as a compensation for the 'burden' of taxation. From 2004 onwards, it was called distribution subsidy, reduced in its yearly amount, but still eligible for nearly

5 See Murschetz/ Karmasin 2014 or Trappel 2015 for a detailed discussion. 
all dailies. The available funds are divided into equal parts among all applicants; if one corporation publishes more than one eligible newspaper, the amount is reduced according to a pre-set key defined in the law.

Whereas the non-targeted subsidies were subject to criticism from the start, the diversity subsidy is more promising to serve as a media policy. Daily newspapers that are not in a dominant position get funding up to the ceiling of 100,000 copies sold, provided that more than 50 per cent of their pages are used for editorial content (not advertising) and the daily employs at least 12 journalists full time. Eligible newspapers receive a lump sum of 500,000 euros per year and an additional premium depending on the copies sold. The following four papers were beneficiaries of this subsidy type in 2016: Der Standard, Die Presse, Neue Vorarlberger Tageszeitung, Neues Volksblatt). Historically, this diversity subsidy was introduced to stop further concentration by enabling smaller newspapers to survive. Unfortunately, it was implemented only after the closure of several regional and one national dailies in the late 1980s, when the dominance of one national tabloid paper (Kronen Zeitung with a reach of $43 \%$ then) already seemed impossible to overcome.

Direct press subsidies are said to embody the danger of excessive state power over the press. Austria tried to override this criticism by making those press subsidies a law and the committee preparing the decisions a neocorporatist body. Although there is no empirical evidence of any government intervention in content, the amount allocated is subject to political decisions (Trappel 2015, 195). This insecurity could be labelled a threat for newspapers as such.

Besides all criticism, the direct press subsidy scheme helps newspapers to survive in the small market Austria. Although we lack hard facts concerning the otherwise possible closing of dailies, the industry is supported, and subsidies for (hopefully) quality papers with a certain, but not too high market share serve the purpose of ensuring or increasing diversity. 


\subsection{Media Policies - Not Prepared for the Digital Age}

The institutional settings found in the Austrian policy system allowed for a rather stable press market, albeit not a highly dynamic one. So far, Austrian media policies have not been redesigned to fit the Digital Age, as shown in the section above: Press subsidies are oriented towards the printed press only, with no subsidy scheme for digital outlets as such.

In recent years, there have been government efforts to reform the press subsidy law, the last one with the promise of a bill presented in 2017. ${ }^{6}$ During the last number of years, the quite influential newspaper publishers' association has been pressing for a reform of the subsidy scheme, in fact mainly for an increase in the subsidies provided. In a slightly cynical view, one could conclude: the bigger the crisis, the higher the demands by the publishers' association.

The plans of the last government, according to press releases in the first half of 2017, were to increase press subsidy to 17 million euros. This was to be financed by an extension of the advertisement tax to online advertisements (in Google, Facebook and the like). A radical change concerned the eligibility requirements for subsidies: A minimum of journalists employed and the membership in self-regulating bodies were debated as possible criteria. Free dailies and digital outlets were added as potential beneficiaries, the latter with the idea it could lead to new outlets or at least innovations in the field (Der Standard 2016; Profil 2017).

\subsection{Antitrust Law: Hardly Serving its Purpose}

The aim of Antitrust Laws is to deal with mergers and acquisitions, to hinder the abuse of dominance and anticompetitive agreements, thereby assuring that competition is maintained and the assumed benefits of market forces can

6 The termination of the government coalition by the Austrian People's Party, and the subsequent elections in autumn 2017, have thwarted the press subsidy law from being reformed. 
operate. For a long time, Austria had no effective Antitrust Law at all, not seeing it as necessary: mergers were viewed as positive for Austria's competitiveness against other countries (Reitzner 1989). In 1993, the Austrian parliament passed an Antitrust Law, which for the first time had special, stricter requirements for mergers between media enterprises. This law was introduced a few years after big mergers (for example, Mediaprint) took place. While the wording of the law was strict, its execution still proved to be susceptible to political interest, as showcased by the dubious Formil fusion in 2001 (Fidler 2008). Besides, it did not include any decartelization measures. Therefore, the law is sometimes referred to as a 'cementation of the status quo'. The main problems with decartelization are on one hand, political acceptability, on the other, a possible negative effect on the competitiveness of the home industry compared to foreign companies, the absence of economies of scale and scope reducing the quality of the papers.

In general, we find problems of implementation and control of antitrust measures, particularly in closing loopholes. All this leads to the succinct characterisation of the Antit-rust Law as: 'It might not do any good, but at least it does not do any harm' (Lange 2008).

\section{Companies' Strategies Managing Maturity and Decline}

In these uncertain times for media companies, Austrian newspaper firms draw from a repertoire of established strategies to mitigate the disruptive effects of changing consumer habits, technological change and decline in ad revenue.

\subsection{Protecting and Nourishing (?) Home Markets}

The concurrence of historical contingencies and structural constraints of media economics led to the establishment of highly pronounced regional newspaper markets that are in effect controlled by few - sometimes only one - publishers. An overarching theme of the Austrian press landscape is that the dominant market positions are secured by regionalisation and 
localisation of the published content, therewith providing both ad space and readers for the regional industries and local news for its readership. The regionalisation strategies of media groups go beyond daily newspapers, and include cross-ownership of weeklies and regional radio/TV channels. The hegemony on the provincial markets is also secured through vertical concentration, especially regarding print operations and distribution. Of course, such barriers can hardly be constructed for online content, but as highlighted before, online consumption often draws on habits towards already established offline brands. In the case of free dailies, some incumbent publishers, e.g. Mediaprint and Moser Holding, introduced their own free dailies to block the market for other competitors.

There seems to be broad consensus within the industry that the growth potential of business models for paid content is doubtful. First, the only successful daily newspapers that have entered the market within the last twenty years are free dailies. Second, all daily newspapers provide free-of-charge online outlets. While most online outlets are not profitable, the willingness to establish mechanisms such as paywalls is limited, since this would substantially threaten online reach. Third, in recent years several newspaper publishers took hold of the market for regional free weeklies by acquisitions and mergers. This may be due to potential economies of scale and scope, but also helped to enforce the strong regional foothold of publishers. Furthermore, free weeklies arguably offer one of the safest bets for publishing houses today. They are still attractive to advertisers and they are distributed through unsolicited delivery to basically every household. Hence, publishers are not constrained to metropolitan areas, as in the case of free dailies, and they enjoy a guaranteed high reach which is a rather nice thing in such uncertain times. However, this strong emphasis of the Austrian press on free-of-charge products arguably further undermines consumers' willingness to pay. 


\subsection{Strategic Alliances as Strategies of Diversification}

Strategic alliances are established with domestic and international partners. One of the most striking and - considering antitrust laws - questionable examples in recent years is the cooperation between the second and third largest newspaper publishers, Styria Media Group and Moser Holding. In 2009, they formed a highly profitable subsidiary, Regionalmedien Austria, which publishes 126 weeklies with a combined reach of almost 50\% (MA 2016). Kurier and Kronen Zeitung, in contrast, cooperate with a mobile network operator, offering mobile phone and mobile internet services bundled together with digital news subscriptions.

Strategic alliances with international partners have also gained importance. For example, while almost all newspapers offer in-house services for classified ads on their websites, the Styria Media Group opted to rely on the expertise of Norwegian's largest publisher, Schibsted Media Group ${ }^{7}$. Together they operate Austria's largest online marketplace, willhaben.at, accomplishing a reach of more than $40 \%$ in 2016 (OeWA 2016). Such a course of action is also showcased in the recent involvement of the Swiss publishing group Tamedia in the free daily Heute. Tamedia acquired a $25.5 \%$ interest in the print operations of Heute and a majority interest of $51 \%$ in Heute's online presence.

This interaction with foreign partners shows an economic rationale: While the printed press does not hold promise for viable profits anymore, online activities, e.g. in the classified sector, still do, making it attractive for foreign companies to enter the Austrian market. From the perspective of Austrian media companies, foreign partners provide essential expertise for digital endeavours.

7 Schibsteds division for classifieds already operates in 24 countries (Schibsted 2016). 


\section{Conclusion}

In recent years, radical changes have marked the Austrian newspaper landscape: The emergence of free dailies in the mid2000 s led to further tabloidization, but also formally lowered media concentration. Online outlets of newspapers are constantly expanding, but definitive business models for digital endeavours are not in sight. Maturity and decline characterize the traditional newspaper markets. For now, increasing subscription prices successfully counteract declining print sales, but the failure to attract young readers bodes ill for a sustainable long-term perspective. The advertising market has not recovered from the (financial) ramifications of the Great Recession. These factors are aggravated by the steady growth of online media.

The media subsidy scheme and antitrust legislation have been - above all - able to secure the status quo. In recent years, reforms of the subsidy schemes are discussed (but so far not decided) to accommodate some of the structural changes. Under these circumstances, publishing houses pursue several strategies, e.g. protecting their dominance in regional markets and increasingly forming strategic alliances with domestic and international partners. Curiously, these strategies are constrained and influenced by factors that are reminiscent of some of Grisold's (1996) findings on the structure of Austrian media markets: "Most are small or medium-sized enterprises, they are risk-averse, and most of them have neither the necessary capital structure nor the [...] know-how which would encourage investment in the industry" (Grisold 1996, p. 491). This still appears to hold true two decades later, and may have become even more relevant in the face of changing consumer preferences and digital transition.

\section{References}

Bakker, P., \& Seethaler, J. (2009). Supporting Concentration or Promoting Diversity? The Impact of Free Dailies on the Austrian Newspaper Market. In Stark, B. \& Magin, M. (ed.), Die österreichische Medienlandschaft im Umbruch. Wien: Verlag OeAW.

Best, S., \& Engel, B. (2016). Generationenprofile in der konvergenten Medienwelt. Media Perspektiven (1), 2-26. 
Der Standard (2016). Presseförderung 2017 budgetiert wie heuer: 8,5 Millionen. http://bit.ly/2m8kHKp

Eimeren, B. van, \& Koch, W. (2016). Nachrichtenkonsum im Netz steigt an - auch klassische Medien profitieren. In Media Perspektiven, (5), 277-285

Fidler, H. (2008). Österreichs Medienwelt von A bis Z. Wien: Falter Verlag.

Grisold, A. (1996). Press Concentration and Media Policy in Small Countries. In European Journal of Communication (11), 485-509.

Hallin, D. C., \& Mancini, P. (2004). Comparing Media Systems. Three Models of Media and Politics. Cambridge, England: Cambridge University Press.

Kaltenbrunner, A. (2013). Innovativ? Ja, aber. Die unterschiedliche Bereitschaft zu Veränderung. In A. Kaltenbrunner, M. Karmasin, \& D. Kraus (ed.), Der JournalistenReport IV. Medienmanagement in Österreich. (pp. 53-75). Wien: Facultas.

Lange, B.-P. (2008). Medienwettbewerb, Konzentration und Gesellschaft, Interdisziplinäre Analyse von Medienpluralität in regionaler und internationaler Perspektive. Wiesbaden.

Murschetz, P., \& Karmasin, M. (2014). Austria: Press subsidies in search of a new design. In P. Murschetz (ed.), State Aid for Newspapers. Theories, Cases, Actions. (pp. 133-148). Heidelberg: Springer.

Profil (2017). Presseförderung für Gratis-Zeitungen: http://bit.ly/2149byB

Puppis, M. (2009). Media Regulation in Small States. In International Communication Gazette 71 (1-2), 7-17.

Schibsted (2016). Q2 Interim Report. January-June 2016. http://bit.ly/21ILoYP

Steinmaurer, T. (2002). Konzentriert und verflochten. Österreichs Mediensystem im Überblick. Innsbruck: StudienVerlag.

Thurman, N. (2014). Newspaper Consumption in the Digital Age. Measuring multichannel audience attention and brand popularity. In Digital Journalism 2(2).

Trappel, J. (2015). Media Subsidies: Editorial Independence Compromised? In S. Barnett, \& J. Townend (ed.), Media Power and Plurality. From Hyperlocal to HighLevel Policy. (pp. 187-200). Springer.

Trappel, J. (1991). Medien Macht Markt. Medienpolitik westeuropäischer Kleinstaaten. Wien: Österreichischer Kunst- und Kulturverlag.

Trilling, D., \& Schoenbach, K. (2013). Patterns of News Consumption in Austria: How Fragmented Are They? In International Journal of Communication 7, 929-953.

Veblen, T. (1899). The Theory of the Leisure Class: An Economic Study of Institutions

\section{Databases}

Firmen-Compass (2016). https://compass.at

Fokus-Institut (2016). http://www.focus-institut.com

MA (2016). http://www.media-analyse.at

OeAK (2016). http://www.oeak.at

OeWA (2016). http://www.oewa.at

RTR (2016). https://www.rtr.at

\section{@Q) $\Theta \Theta$}

Published under a Creative Commons Licence

«Attribution - NonCommercial - NoDerivs 4.0 International»

(CC BY-NC-ND) 